\title{
Transmission of Human Papillomavirus Without Sexual Contact
}

\section{Panteha TAVASSOL ${ }^{*}$, Naweed AHMED ${ }^{2}$, Wakqas KAYANI, Sahab JAMSHIDI, Suneil BAPAT, Ahmed IMAMOVIC}

1 Student, University of Guelph, Canada

2 Researcher, Medical University of the Americas, St. Kitts and Nevis

*Auteur(e) correspondant | Corresponding author : panteha.tavassol@gmail.com

\section{Résumé :}

(traduction)

Mots-clés :
Le virus du papillome humain (VPH) est une des infections sexuellement transmissibles les plus répandues. Il existe quatre types de VPH : 6, 11, 16, et 18 . Les types 6 et 11 causent les condylomes acuminés alors que les types 16 et 18 sont asymptomatiques chez les hommes, mais peuvent évoluer en cancer du col utérin chez les femmes. Bien que ce soit rare, un faible pourcentage d'hommes et de femmes ont reçu le diagnostic du VPH malgré l'absence de contact sexuel antérieur. Dans cette étude, nous discutons le cas d'un jeune homme de 15 ans de l'Asie du Sud qui a contracté un type inconnu de VPH à faible risque sans avoir eu de contact sexuel. Le VPH est extrêmement contagieux, mais en général, le système immunitaire est capable de contrôler l'infection et de prévenir l'apparition de condylomes acuminés. Dans ce cas, il est important d'empêcher la propagation d'infections virales. Plusieurs déterminants de la santé affectent la transmission du VPH, notamment le revenu, le statut social, le réseau de soutien social, l'éducation et l'alphabétisme, la culture, les environnements sociaux et physiques, ainsi que les services de santé. Pour contribuer à la prévention du VPH, l'éducation sexuelle devrait être enseignée dans les écoles dès un jeune âge et le vaccin Gardasil ${ }^{\circledR}$ devrait être administré aux femmes ainsi qu'aux hommes dès le bas âge afin de réduire le fardeau de la maladie et l'incidence du VPH.

VPH, non sexuel, mâle, Gardasil $®$

Human papillomavirus (HPV) is one of the most common sexually transmitted infections. There are four common HPV strains: 6, 11, 16, and 18. Strains 6 and 11 cause genital warts, while strains 16 and 18 are asymptomatic in males and may progress to cervical cancer in females. Although uncommon, a small percentage of males and females have been diagnosed with HPV without previous sexual contact. In this case report, we discuss a case conducted on a 15-year-old South Asian male who contracted an unknown low-risk strain of HPV with no history of sexual contact. HPV is highly infectious, however in the majority of cases the immune system is able to clear the infection, preventing the appearance of genital warts. In cases such as these, it is important to help control the spread of viral infections. Several determinants of health are involved in and affect the transmission of HPV, including income and social status, social support networks, education and literacy, culture, social and physical environments, and health services. To aid in the prevention of HPV, sexual education should be taught at early ages within schools and the Gardasil $(\AA$ vaccine should be administered to both females and males at an early age to reduce the burden of disease and the incidence of HPV.

HPV, nonsexual, male, Gardasil® 


\section{Introduction}

Human papillomavirus (HPV) is one of the most common sexually transmitted infections in the world. HPV can be spread through vaginal, anal, or oral sex with someone who is infected with the virus. Although uncommon, a small percentage of males and females have been diagnosed with HPV with no prior sexual contact (Sonnex, Strauss, \& Gray, 1999; Strauss, 2002). It is estimated that $75 \%$ of Canadians and $60 \%$ of college-aged American women will have at least one HPV infection in their lifetime (Ho, Bierman, Beardsley, Chang, \& Burk, 1998; Marra, Ogilvie, Colley, Kliewer, \& Marra, 2008). The four most common strains of HPV are $6,11,16$, and 18 . Lower-risk strains 6 and 11 may cause genital warts, while higher-risk strains 16 and 18 are asymptomatic in males and may progress to cervical cancer in females (Grimes, Benjamins, \& Williams, 2013). Most strains of HPV infection remain asymptomatic in males and females causing the disease to be difficult to detect and treat.

The control and transmission of viral infections, such as HPV, are affected by several determinants of health. This includes income and social status, available social support networks, culture, and social and physical environments, as these may impact one's access to resources for infection prevention and treatment. As well, HPV transmission is affected by the education and literacy and the health services available for children in schools. Early education and direct treatment in school health services are strong primary control and preventative measures. Another determinant of health that is involved in the transmission of HPV is gender. A false stigma about HPV is that it is only necessary for females to be given the HPV vaccine because they are the ones at risk of cervical cancer. However, it is important for males to be vaccinated at an early age as well because there are several other cancers that also affect males, such as mouth, throat, and anal cancers.

There are significant costs associated with treating an HPV infection. Treatment may include removal of genital warts, suppression of viral replication, and surgery or radiation if the virus has progressed to cancer (The Society of Obstetricians and Gynaecologists of Canada [SOGC], 2014). The treatment and therapy costs continue to rise, which increases the importance of prevention of the infection through HPV education and vaccination. The purpose of this paper is to emphasize the importance of HPV prevention through vaccination and education about HPV. It is particularly important since the virus can be transmitted both sexually and non-sexually; therefore, more people are at risk of infection.

\section{Materials and Methods}

A 15-year-old South Asian male contracted an unknown low -risk strain of HPV with no history of sexual contact. This deduction was reached after education of the patient was performed to determine a source of transmission and after a thorough history was conducted. Sexual contact for the purpose of this case will be defined as penetrative genital contact, oral-genital contact, or genital-genital contact. The patient presented with a single three millimetre cauliflowerlike genital lesion on the ventral aspect of his penis, which was treated unsuccessfully on multiple occasions. After ten physician visits, he was given six treatments of Histofreezer $\AA$, two treatments of Condyline $\AA$, and one treatment of Aldara $\AA$, totalling $\$ 1340$ in treatment costs (see Table 1). At his next follow-up appointment, the patient will undergo a biopsy and will be referred to a dermatologist for continuation of care. The patient will be followed to determine the HPV strain and to follow through with his ongoing treatment plan.

\section{Table 1 personal communication, July 5, 2014).}

\begin{tabular}{|l|c|}
\hline \multicolumn{1}{|c|}{ Treatment } & Cost \\
\hline Histofreezer $囚$ (cryotherapy), six treatments & $\$ 350$ \\
$\begin{array}{l}\text { Condolyne } ® \text { (topical solution) 0.5\%, two } \\
\text { treatments }\end{array}$ & $\$ 120$ \\
Aldara $囚$ (Imiquimod), one treatment & $\$ 420$ \\
Physician appointment, ten visits & $\$ 450$ \\
Total cost & $\$ 1340$ \\
\hline
\end{tabular}

A study in sexually transmitted infections reported that the HPV virus has been found underneath the fingernails of individuals with genital warts (Sonnex et al., 1999). HPV has the ability to retain up to $30 \%$ of its infectivity for seven days at room temperature after known contact with fomites (Roden, Lowy, \& Schiller, 1997). This allows the transmission of HPV by means of manual-genital contact, which is a speculation of how the patient in this case may have contracted the virus. HPV is known to be highly infectious, but in the majority of cases, the immune system is able to clear the infection or suppress the onset of symptoms. However, the virus may remain dormant in the body for many years (Waller, McCaffery, Nazroo, \& Wardle, 2005). In such cases, it is important to help control the spread of the virus. 


\section{Discussion and Conclusion}

It is becoming more difficult to control HPV infection due to the additional possibility of non-sexual transmission. The treatment of genital warts and HPV-associated diseases also has cost implications. In Canada, the average cost of treatment per episode of genital warts is $\$ 207$ for women and \$176 for men (Marra, Ogilvie, Colley, Kliewer, \& Marra, 2009). General treatment may include cryotherapy, topical creams, and immune system repressive drugs (SOGC, 2014). The type of treatment and frequency of administration depend on the severity or duration of the case. The most effective way to prevent HPV infection is through vaccination. A study by the National Advisory Committee on Immunization (NACI; 2012) showed that the vaccine had 85.6\% efficacy against infection of strains $6,11,16$, and 18 amongst 16-26 year-old men in Canada (see Table 2).

The HPV vaccine reduces the cost burden, as it prevents both genital warts and cervical cancer. In the United-States, the annual cost of death and disease from cervical cancer is around \$270,000,000 (Brown, Riley, Schussler, \& Etzioni, 2002). In addition to vaccination, another preventative technique is education (Weinstock, Berman, \& Cates, 2004). Adolescent males and females should be educated about sexual and non-sexual means of HPV transmission and the potentially dangerous implications to their health. Proper education will increase their likelihood to take appropriate precautions, such as washing their hands more often and using protection during any form of sexual intercourse.

One of the main reasons parents do not get their children HPV-vaccinated is due to a lack of education (Stokley et al., 2014). Many people do not have sufficient knowledge on modes of HPV transmission, preventative options, and the potentially dangerous effects on health (Holcomb, Bailey, Crawford, \& Ruffin, 2004). Stokley et al. (2014), reported that lack of knowledge was the top reason for females (see Figure 1) and the third top reason for males (see Figure 2) not getting the HPV vaccine. A survey conducted in Toronto high schools reported that $87 \%$ of students have not heard of HPV (Dell, Chen, Ahmad, \& Steward, 2000). With proper education, more youth will be aware of the significance of HPV and the false stigmas about HPV vaccinations, particularly for males, can be reduced.

\section{Table 2 Efficacy of HPV vaccine in young men 16-26 years of a ge in Canada (NACl, 2012).}

\begin{tabular}{|c|c|c|c|c|c|}
\hline Endpoint & $\begin{array}{c}\text { HPV4 } \\
\text { Gardasil } @ \text { Cases } \\
(\mathrm{n}=1397)\end{array}$ & $\begin{array}{l}\text { Placebo Cases } \\
\quad(n=1408)\end{array}$ & Efficacy (\%) & $95 \%$ CI & P-value \\
\hline All external genital lesions (EGL) & 3 & 31 & $\begin{array}{l}90.4 \text { (all types) } \\
84.3 \text { (type 6) } \\
90.9 \text { (type } 11 \text { ) } \\
100 \text { (type } 16) \\
100 \text { (type } 18 \text { ) }\end{array}$ & $\begin{array}{c}69.2-97.6 \\
46.5-97.0 \\
37.7-99.8 \\
0-100 \\
0-100\end{array}$ & $<0.001$ \\
\hline $\begin{array}{l}\text { Persistent infections (HPV types } \\
6,11,16,18 \text {-related) }\end{array}$ & 15 & 101 & 85.6 & $73.4-92.9$ & $<0.001$ \\
\hline HPV type 6-related & 4 & 33 & 88 & $66.3-96.9$ & \\
\hline HPV type-11 related & 1 & 15 & 93.4 & $56.8-99.8$ & \\
\hline
\end{tabular}


HPV immunization in Canada and the United States is voluntary; therefore, the success of the HPV vaccine depends on the public's acceptance of the vaccine. A common barrier to acceptance is the belief that the vaccine will promote an early onset of sexual activity in children. Although the virus is transmitted primarily through sexual contact, the vaccine protects against both sexual and non-sexual forms of HPV transmission. Administering the vaccine at an early age allows time for an immune response to develop before the individual is at greater risk of infection following the onset of sexual activity. Holcomb et al. (2004), reported that $86.2 \%$ of individuals prefer to have learned about HPV before becoming sexually active. The most common and

\section{Figure 1}

Top reasons parents do not give

their daughters the HPV vaccine (Stokley et al., 2014).

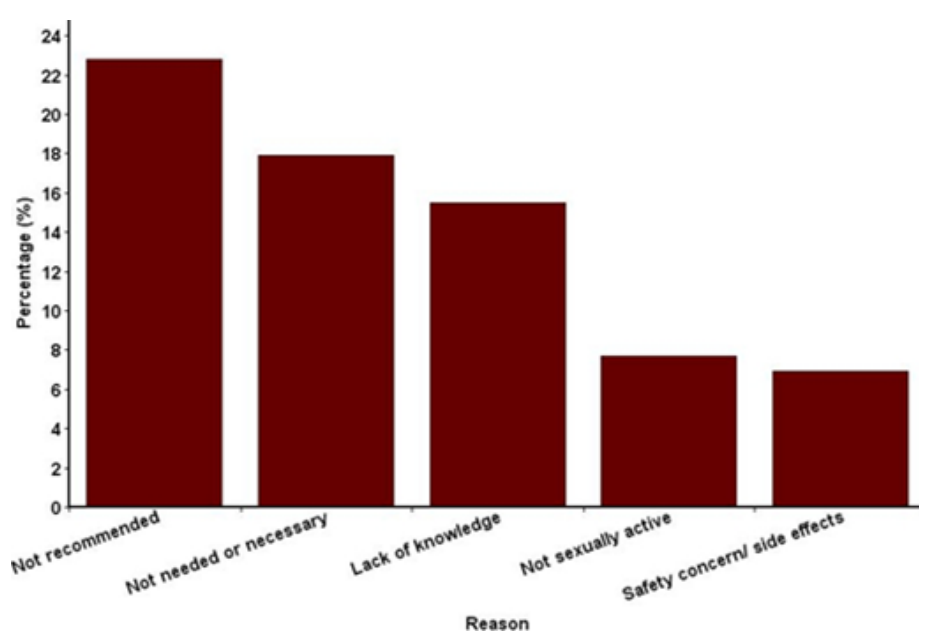

Top reasons parents do not give

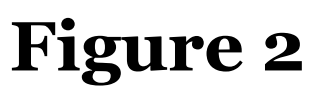
their sons the HPV vaccine (Stokley et al., 2014).

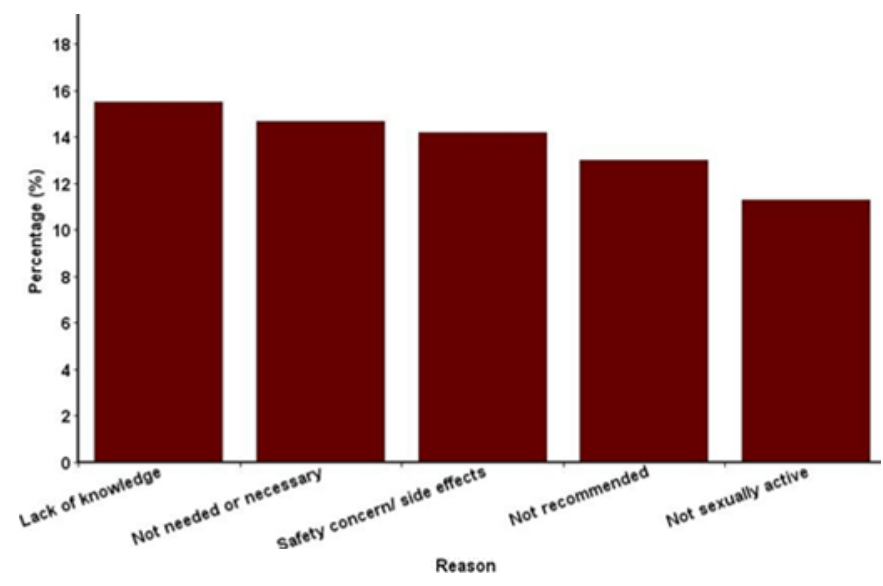

effective HPV vaccine for males and females is Gardasil $®$, which is a quadrivalent vaccine against strains $6,11,16$, and 18 (Stokley et al., 2014). Apart from mild adverse effects common to most vaccines, such as local pain in the arm where the shot was given, fever, and nausea, there are no serious safety concerns associated with the vaccine because it does not involve live viral material (Stokley et al., 2014).

The spread of HPV may be lessened by preventative measures: education at a young age and vaccination for both males and females. In our case, neither the vaccine was given nor was the patient ever educated about HPV. These measures could have prevented the non-sexual transmission of HPV to the patient.

\section{References}

Brown, M. L., Riley, G. F., Schussler, N., \& Etzioni, R. (2002). Estimating health care costs related to cancer treatment from SEER-Medicare data. Medical Care, 40 (Suppl 8), 104-117. Retrieved from http://www.jstor.org/ stable/3767931

Dell, D. L., Chen, H., Ahmad, F., \& Steward, D. E. (2000). Knowledge about human papillomavirus among adolescents. Obstetrics \& Gynecology, 96(5 Pt 1), 653-656. doi:10.1016/So029-7844(00)01009-7

Grimes, R. M., Benjamins, L. J., \& Williams, K. L. (2013). Counseling about the HPV vaccine: Desexualize, educate, and advocate. Journal of Pediatric \& Adolescent Gynecology, 26(4), 243-248. doi:10.1016/j.jpag.2013.04.002

Ho, G. Y., Bierman, R., Beardsley, L., Chang, C. J., \& Burk, R. D. (1998). Natural history of cervicovaginal papillomavirus infection in young women. The New England Journal of Medicine, 338(7), 423-428. doi:10.1056/

NEJM199802123380703

Holcomb, B., Bailey, J. M., Crawford, K., \& Ruffin, M. T. (2004). Adults' knowledge and behaviors related to human papillomavirus infection. The Journal of the American Board of Family Medicine, 17(1), 26-31. doi:10.3122/ jabfm.17.1.26

Marra, F., Ogilvie, G., Colley, L., Kliewer, E., \& Marra, C. A. (2009). Epidemiology and costs associated with genital warts in Canada. Sexually Transmitted Infections, 85(2), 111-115. doi:10.1136/sti.2008.030999

National Advisory Committee on Immunization. (January, 2012). Update on human papillomavirus vaccines. Retrieved from http://www.phac-aspc.gc.ca/publicat/ccdr- 
rmtc/12vol38/acs-dcc-1/assets/pdf/12vol-38-acs-dcc-1eng.pdf

Roden, R. B., Lowy, D. R., \& Schiller, J. T. (1997). Papillomavirus is resistant to desiccation. The Journal of Infectious Diseases, 176(4), 1076-1079. doi:10.1086/516515

Sonnex, C., Strauss, S., \& Gray, J. J. (1999). Detection of human papillomavirus DNA on the fingers of patients with genital warts. Sexually Transmitted Infections, 75(5), 317319. doi:10.1136/sti.75.5.317

Stokley, S., Jeyarajah, J., Yankey, D., Cano, M., Gee, J., Roark, J.,...Centers for Disease Control and Prevention (CDC). (2014). Human papillomavirus vaccination coverage among adolescents, 2007-2013, and postlicensure vaccine safety monitoring, 2006-2014-United States. Morbidity and Mortality Weekly Report, 63(29), 620-624. Retrieved from https://www.cdc.gov/mmwr/preview/mmwrhtml/ mm6329a3.htm

Strauss, S., Sastry, P., Sonnex, C., Edwards, S., \& Gray, J. (2002). Contamination of environmental surfaces by genital human papillomaviruses. Sexually Transmitted Infections, 78(2), 135-138. doi:10.1136/sti.78.2.135

The Society of Obstetricians and Gynaecologists of Canada. (2014). Challenges and Costs of Detection. Retrieved from hpvinfo.ca.

Waller, J., McCaffery, K., Nazroo, J., \& Wardle, J. (2005). Making sense of information about HPV in cervical screening: A qualitative study. British Journal of Cancer, 92(2), 265-270. doi:10.1038/sj.bjc.6602312

Weinstock, H., Berman, S., \& Cates, W. (2004). Sexually transmitted disease among American youth: Incidence and prevalence estimates, 2000. Perspectives on Sexual and Reproductive Health, 36(1), 6-10. doi:10.1363/3600604 